\title{
Zastupljenost vještina kritičkoga mišljenja u ishodima učenja međupredmetnih tema
}

Rona Bušljeta Kardum*

rbusljeta@hrstud.hr

https://orcid.org/0000-0002-7158-0044 https://doi.org/10.31192/np.18.3.3

UDK: 159.955:165.021

37.016:159.955

Prethodno priopćenje /

Preliminary communication

Primljeno: 1. lipnja 2020.

Prihvaćeno: 29. rujna 2020.

Vrijeme u kojem živimo i radimo traži od pojedinca različite kompetencije koje će mu omogućiti kvalitetnije djelovanje u svim aspektima života. Jedna je od tih kompetencija $i$ kritičko mišljenje koje uključuje niz različitih vještina, poput rješavanja problema, donošenja odluka, argumentiranog zaključivanja $i$ vrednovanja na temelju kriterija. Budući da se kritičko mišljenje često smatra jednom od ključnih kompetencija za život i rad u 21. stoljeću, ne čudi činjenica da se važnost razvijanja kritičkog mišljenja naglašava kada je u pitanju odgojno-obrazovno djelovanje. Iako se kod nas vrlo malo pisalo o kritičkom mišljenju u okviru odgojno-obrazovnog procesa, važnost razvoja kritičkog mišljenja u procesu poučavanja i učenja naglašava se u kurikularnim dokumentima. S obzirom na to, cilj ovoga rada je utvrditi, na temelju analize ishoda učenja, koje se vještine kritičkoga mišljenja i u kojoj mjeri potiču međupredmetnim temama. Dobiveni rezultati pokazat će ostvaruju li medupremetne teme jednu od svojih uloga, a to je prihvaćanje i uvažavanje važnosti razvoja kompetencije kritičkog mišljenja u procesu poučavanja $i$ učenja.

Ključne riječi: ishodi učenja, kritičko mišljenje, kurikulum, međupredmetne teme, odgoj i obrazovanje.

\footnotetext{
* Doc. dr. sc. Rona Bušljeta Kardum, Sveučilište u Zagrebu, Fakultet hrvatskih studija, Borongajska cesta 83d, HR-10000 Zagreb.
} 


\section{Uvod}

Budući da živimo u svijetu stalnih promjena i brzog napretka na svim poljima te da smo zahvaljujući različitim medijima izloženi velikom broju informacija, vrlo je važno da imamo različite vještine koje nam omogućuju uspješno procjenjivanje, zaključivanje i djelovanje. Odgovornost za razvoj tih vještina je, $\mathrm{s}$ jedne strane na obitelji, a s druge na odgojno-obrazovnim ustanovama.

Obrazovanje se danas definira kao cjeloživotni proces koji se treba prilagođavati društvenim promjenama. ${ }^{1} \mathrm{U}$ tom kontekstu učenje se gleda kao potraga za novim spoznajama, zanimljivo putovanje i nezamjenjivo iskustvo stjecanja novih znanja i vještina, proces razumijevanja i prihvaćanja drugačijih stavova i vrijednosti te inspiracija za stvaranje bolje sadašnjosti i budućnosti. Dakle, proces poučavanja treba biti usmjeren na učenika i to tako da glavni cilj poučavanja bude način kako učenika naučiti misliti, odnosno preuzeti odgovornost za vlastiti proces promišljanja, vrednovanja, analiziranja i zaključivanja utemeljen na provjerenim činjenicama, a sve radi samostalnog i odgovornog sudjelovanja u svim područjima života. ${ }^{2}$

Nerijetko se kao jedna od ključnih kompetencija u pripremi učenika za izazove koje nosi život i rad u 21. stoljeću ističe kritičko mišljenje koje predstavlja i jedan od ključnih ciljeva procesa odgoja i obrazovanja na svim razinama. ${ }^{3}$

Važnost kritičkog mišljenja istaknuta je temeljnim odgojno-obrazovnim dokumentom Republike Hrvatske - Okvirom nacionalnoga kurikuluma (ONK). Tim se dokumentom kritičko mišljenje izdvaja kao jedna od generičkih kompetencija. Generičke kompetencije su one kompetencije koje treba imati svaki pojedinac bez obzira na vrstu i stupanj obrazovanja. Kritičko mišljenje se, uz rješavanje problema i donošenje odluka, metakogniciju te kreativnost i inovativnost, navodi kao dio grupe generičkih kompetencija koje se odnose na oblike mišljenja. Konkretno, kritičko mišljenje se opisuje kao kompleksna

${ }^{1}$ Usp. H. GUDJONS, Pedagogija - temeljna znanja, Zagreb, EDUCA, 1994, 164-165.

${ }^{2}$ Usp. D. TOT, Učeničke kompetencije i suvremena nastava, Odgojne znanosti, 12 (2010) 1, 65-78; M. KOLUDROVIĆ, Mogućnosti razvijanja kompetencija učenja u suvremenoj nastavi, Pedagogijska istraživanja, 10 (2103) 2, 295-307; M. ŠTEVANIĆ-PAVELIĆ, I. VLASAC, Postignuća učenika primjenom različitih metoda i oblika rada u nastavi prirode i društva, Život $i$ škola, 52 (2006) 1-2, 155-165.

${ }^{3}$ Usp. B. TRILlING, C. FADEL, $21^{\text {st }}$ Century Skills. Learning for Life in Our Times, San Francisco, CA, Jossey-Bass, 2009, 50. U dokumentu naziva Projekt hrvatskog odgojno-obrazovnog sustava za 21. stoljeće navodi se da odgojno-obrazovni sustav treba ne samo podržati i razviti intelektualnu radoznalost i želju za učenjem, nego i osposobiti učenika/studenta za samostalno učenje, kritičko mišljenje te razumijevanje svijeta, upoznavanje i prihvaćanje drukčijih pojedinaca i naroda, za otkrivanje vlastita identiteta i usvajanje zajedničkih vrijednosti Europe i svijeta [usp. Projekt hrvatskog odgojno-obrazovnog sustava za 21. stoljeće, Zagreb, Ministarstvo prosvjete i športa, 2002, 15]. Važnost kritičkog mišljenja ističe se i Strategijom obrazovanja, znanosti i tehnologije navodeći između ostalog da je zadatak procesa odgoja i obrazovanja poticanje kritičkoga mišljenja (usp. Strategija obrazovanja, znanosti i tehnologije, Zagreb, Ministarstvo znanosti, obrazovanja i sporta, 2014, 31). 
mješavina brojnih vještina koje uključuju argumentirano iznošenje vlastitih stavova i razmišljanja, procjenjivanje, vrednovanje i uvažavanje drukčijih ideja i stavova te spremnost na prihvaćanje i mijenjanje vlastitih gledište u skladu $\mathrm{s}$ argumentima. ${ }^{4}$ Također, važno je istaknuti da se spomenutim dokumentom jasno ističe i potreba razvijanja generičkih kompetencija u međupredmetnim temama. Točnije, ostvarivanje ciljeva i odgojno-obrazovnih očekivanja iskazanih u nacionalnim kurikulumima međupredmetnih tema obvezno je na svim razinama i u svim vrstama odgoja i obrazovanja. ${ }^{5}$ Međupredmetne teme - Građanski odgoj i obrazovanje, Održivi razvoj, Učiti kako učiti, Osobni i socijalni razvoj, Poduzetništvo, Upotreba informacijsko-komunikacijske tehnologije, Zdravlje - obuhvaćaju interdisciplinarne odgojno-obrazovne sadržaje kojima je, između ostalog, cilj proširivanje znanja i vještina izvan okvira pojedinih predmeta. Drugim riječima, međupredmetne teme su obvezujući i integralni dio svakog predmetnog kurikuluma te čine interakcijsko ispreplitanje i povezivanje različitih sadržaja radi stjecanja generičkih znanja i vještina, od kojih je jedna i kritičko mišljenje. Koje su vještine kritičkog mišljenja i koliko zastupljene u međupredmetnim temama moguće je utvrditi na temelju analize kurikulumima predloženih odgojno-obrazovnih očekivanja.

\section{Definiranje kritičkog mišljenja u okviru odgojno-obrazovnog procesa}

Teško je definirati što je kritičko mišljenje s obzirom na to da ono integrira različite vještine, ali i različite aktivnosti, vrijednosti i stavove. Znanosti poput filozofije, psihologije, kao i odgojno-obrazovnih znanosti, s obzirom na različite kontekste, imaju drukčija polazišta u objašnjenju kritičkoga mišljenja. Tako se, primjerice, u filozofiji, najjednostavnije rečeno, kritičko mišljenje sagledava s obzirom na promišljanja i djelovanja antičkih filozofa, posebice Sokrata, ili se kritičko mišljenje veže uz logičku analizu argumenata, prosudbu i zaključivanje. S druge strane, psiholozi kritičko mišljenje analiziraju polazeći od misaonih obrazaca vezanih uz područje kognitivne psihologije te empirijskih istraživanja.

U 20. stoljeću, određivanje važnosti, pozicije i uloge kritičkoga mišljenja s obzirom na proces odgoja i obrazovanja povezuje se s Johnom Deweyjem, američkim filozofom i psihologom. ${ }^{6}$ John Dewey za kritičko mišljenje koristi

\footnotetext{
${ }^{4}$ Usp. MINISTARSTVO ZNANOSTI I OBRAZOVANJA, Prijedlog Okvira nacionalnoga kurikuluma, https://mzo.gov.hr/UserDocsImages/dokumenti/Obrazovanje/NacionalniKurikulum/PodrucjaKurikuluma/DruA1tveno-humanisti\%C4\%8Dko\%20podru\%C4\%8Dje.pdf (15.03. 2020).

5 Usp. isto, 9.

${ }^{6}$ Usp. R. STERNBERG, Critical Thinking. Its Nature, Measurement, and Improvement, Washington, DC, National Inst. of Education (ED), 1986, 4; R. H. ENNIS, Critical Thinking Asse-
} 
pojam refleksivnog mišljenja i suprotstavlja ga svakom drugom mišljenju koje ne traži dodatna propitivanja i dokaze. ${ }^{7}$ Slično ističu i suvremeni autori čiji je uži interes problem kritičkoga mišljenja. Tako se, kritičko mišljenje, na primjer, definira kao refleksivno mišljenje koje daje odgovore na pitanja što činiti i u što vjerovati ${ }^{8}$ ili kao ono koje se temelji na kriterijima i koje je osjetljivo na kontekst, ${ }^{9}$ odnosno kao umjetnost analiziranja i procjenjivanja procesa razmišljanja sa željom njegova poboljšanja. ${ }^{10}$

Navedena razilaženja u tumačenjima kritičkoga mišljenja pokušala su se uskladili 1990. sveobuhvatnim projektom pod okriljem American Philosophical Association, a rezultat je izvješće naziva The Delphi Report. U izradi tog izvješća sudjelovalo je više od 40 stručnjaka iz različitih znanstvenih područja, među kojima je najviše bilo filozofa, ali i psihologa, sociologa te stručnjaka s područja obrazovnih znanosti. U izvješću je ponuđena definicija kritičkoga mišljenja koja je tada široko prihvaćena. Prema toj definiciji, kritičko mišljenje je svrhovita i samoregulirana prosudba koja rezultira interpretacijom, analizom, procjenom i zaključivanjem te objašnjenjem dokaznih, konceptualnih, metodoloških, kriterijskih ili kontekstualnih procesa razmatranja na kojima se ta prosudba temelji. ${ }^{11}$ Osim toga, u izvješću se nudi prikaz i pojašnjenje temeljnih kognitivnih vještina koje se povezuju s kritičkim mišljenjem te se prikazuje način poučavanja i vrednovanja kritičkoga mišljenja. S obzirom na odgovore koje nudi, ne čudi da se The Delphi Report često uzima kao svojevrstan okvir razmatranja kritičkoga mišljenja u kontekstu odgoja i obrazovanja. Dakle, imajući u vidu odgojno-obrazovni kontekst, kritičko mišljenje jest sposobnost pojedinca da donosi racionalne odluke, zaključuje na temelju dokaza, procjenjuje izvore informacija, revidira vlastite prosudbe i mijenja poglede, ponašanje i stavove u svjetlu novih dokaza, a sve radi konstruiranja racionalnih osobnih profesionalnih ili poslovnih odluka te odluka koje se od njega traže kao građanina i državljanina.

ssment, Theory into Practice, 32 (1993) 3, 179-186; M. E. BURBACH, G. S. MATKIN, S. M. FRITZ, Teaching Critical Thinking in an Introductory Leadership Course Utilizing Active Learning Strategies. A Confirmatory Study, College Student Journal, 38 (2004) 3, 482-493; M. AB KADIR, Rethinking Thinking Schools, Learning Nation. Teachers' and Students' Perspectives of Critical Thinking in Singaporean Education, (Unpublished PhD thesis), Melbourne, Melbourne University, 2009, 34; I. BUCHBERGER, Kritičko mišljenje. Priručnik kritičkog mišljenja, slušanja, čitanja i pisanja, Rijeka, Udruga za razvoj visokog školstva Universitas, 2012, 12.

7 Usp. J. G. KURFISS, Critical thinking. Theory, Research, Practice, and Possibilities, Washington, D.C., Association for the Study of Higher Education, 1988, 25; Buchberger, Kritičko mišljenje..., 12.

${ }^{8}$ Ennis, Critical Thinking Assessment..., 180.

9 Usp. M. LIPMAN, Critical Thinking. What Can it Be?, Analytic Teaching, 8 (1987) 1, 5-12.

${ }^{10}$ Usp. R. PAUL, L. ELDER, Consequential Validity. Using Assessment to Drive Instruction, White Paper, http://www.criticalthinking.org/files/White\%20PaperAssessmentSept2007.pdf (15.03.2020).

${ }^{11}$ Usp. P. A. FACIONE, Critical Thinking. A Statement of Expert Consensus for Purposes of Educational Assessment and Instruction. Research Findings and Recommendations, Millbrae, CA, The California Academic Press, 1990, 2. 
Kada se u znanstvenoj literaturi piše o kritičkom mišljenju, nerijetko se navode vještine razvijanja kritičkoga mišljenja. U kontekstu odgojnoobrazovnog procesa te su vještine putokaz za stjecanje ili razvoj kompetencije kritičkog mišljenja kod učenika. U literaturi se najčešće vještine kritičkoga mišljenja dijele na makro i mikro vještine, što upućuje na dvije razine poučavanja i učenja. ${ }^{12} \mathrm{Na}$ makrorazini su: verbalno rasuđivanje, vještine analize argumenata, vještine razmišljanja $\mathrm{i}$ vještine odlučivanja $\mathrm{i}$ rješavanja problema, ${ }^{13}$ odnosno: sistematizacija, analiza, interpretacija, refleksija i evaluacija ${ }^{14} \mathrm{~S}$ druge strane, neki autori nude prikaz vještina kritičkoga mišljenja uzimajući u obzir mikrorazinu te navode: samostalno razmišljanje, osvješćivanje egocentrizma i sociocentrizma, uvježbavanje pravilne procjene, povezivanje kognitivnog i emocionalnog pri procesu razmišljanja, razvoj intelektualne poniznosti i odbacivanje osuđivanja, poticanje misaone hrabrosti, poticanje misaone integrativnosti, ustrajnosti, razložnost, uvažavanje generalizacija i odbacivanje pojednostavljivanja, uspoređivanje analognih situacija, razvoj kriterija prosudbe, analiziranje i procjena argumenata, interpretacija, prepoznavanje kontradikcija, razvoj kriterija procjene. ${ }^{15}$ Osim navedenog, vještine kritičkoga mišljenja na mikrorazini uključuju i vještine poput: procjenjivanje valjanosti izvora, identificiranje zaključaka, razloga i pretpostavki, procjenjivanje kvalitete argumenata, razvijanje i branjenje vlastite pozicije o nekom problemu, postavljanje jasnih dodatnih pitanja itd. ${ }^{16}$

Svojevrstan konsenzus među znanstvenicima, kada su u pitanju vještine kritičkoga mišljenja, postignut je već spomenutim izvješćem u kojem se navodi šest kognitivnih vještina prepoznatih kao temeljne ili ključne za kritičko mišljenje. ${ }^{17}$ Te vještine su: interpretacija, analiza, evaluacija, zaključivanje, objašnjenje i samoregulacija. ${ }^{18}$ Pri tome je interpretacija razumijevanje različitih situacija, prosudbi, postupaka i kriterija. Analiza je identifikacija odnosa između informacija, koncepata, opisa, prosudbi i mišljenja. Evaluaciju

${ }^{12}$ Usp. R. PAUL i dr., Critical Thinking Handbook. High School. A Guide for Redesignig Instruction, Santa Rosa, CA, Foundation for Critical Thinking, 1995, 55.

${ }^{13}$ Usp. D. F. HALPERN, Teaching Critical Thinking for Transfer Across Domains. Dispositions, Skills, Structure Training, and Metacognitive Monitoring, American Psychologist, 53 (1998) 4, 449-455.

${ }^{14}$ Usp. Trilling, Fadel, $21^{\text {st }}$ Century Skills..., 51.

${ }^{15}$ Usp. R. W. PAUL, Critical Thinking. What Every Person Needs to Survive in a Rapidly Changing World, Santa Rosa, CA, Foundation for Critical Thinking, 1990, 306-348.

${ }^{16}$ Usp. R. H. ENNIS, The Nature of Critical Thinking. An Outline of Critical Thinking Dispositions and Abilities, https://education.illinois.edu/docs/default-source/faculty-documents/ robertennis/thenatureofcriticalthinking_51711_000.pdf (20.03.2020).

${ }^{17}$ Usp. Facione, Critical Thinking..., 4.

${ }^{18}$ Kao podvještine temeljnih vještina navedene su: interpretacija - kategorizacije, određenje značenja i pojašnjenje značenja; analiza - ispitivanje ideja, identificiranje argumenata i analiza argumenata; evaluacija - procjena tvrdnji, procjena argumenta; zaključivanje - propitivanje dokaza, prihvaćanje alternative; objašnjenje - navođenje rezultata, opravdavanje procedura, prezentiranje argumenata; samoregulacija - samprocjena, samokorekcija (usp. isto, 6). 
čini sposobnost procjene vjerodostojnosti različitih uvjerenja, stavova i odnosa među opisima i objašnjenjima. Zaključivanje je vještina koja uključuje procese prepoznavanja elemenata potrebnih za zaključivanje, formiranje pretpostavke i hipoteze, određivanje posljedica prosudbi, uvjerenja, mišljenja, koncepata i opisa. Vještina objašnjenja uključuje mogućnosti navođenja razlaganja nečijeg objašnjenja na temelju kriterija te iznošenje vlastitih obrazloženja u obliku jasnih i razložnih argumenata, dok je samoregulacija praćenje vlastitih kognitivnih aktivnosti, odnosno analiza i procjena načina razmišljanja radi otkrivanja pogrešaka i njihova uklanjanja. ${ }^{19}$

Sličnost svih navedenih klasifikacija vještina kritičkoga mišljenja jest da ih zasigurno možemo vezati uz više kognitivne procese. Poticanje viših kognitivnih procesa postalo je imperativ odgoja i obrazovanja 21. stoljeća, a njihovo je ostvarenje uvjetovano načinom formuliranja odgojno-obrazovnih očekivanja te organizacijom procesa poučavanja i učenja.

\section{Poučavanje vještinama kritičkoga mišljenja i proces učenja}

Iako među znanstvenicima postoje neslaganja pri jasnom određenju kritičkog mišljenja, konsenzus je postignut o njegovoj važnosti i ulozi u procesu odgoja i obrazovanja. Zato se danas kritičko mišljenje smatra jednim od ključnih ciljeva odgoja i obrazovanja. ${ }^{20}$

Kritičko je mišljenje kompetencija koja se uči. ${ }^{21} \mathrm{U}$ skladu s tim, kritičko mišljenje valja razvijati, odnosno uvježbavati, te, na koncu, integrirati u odgojno-obrazovni proces kroz kurikulume. ${ }^{22}$ Drugim riječima, kritičko mišljenje treba razvijati tako da se učenike u svakom trenutku misaono potiče i angažira. ${ }^{23}$ Upravo zato proces poučavanja kritičkoga mišljenja zahtijeva holistički pristup, postavljanje učenika u centar procesa poučavanja te poticanje njegove aktivne uloge u procesu učenja. ${ }^{24}$ Aktivno učenje, koje se nerijetko vezuje uz kritičko mišljenje, jest oblik učenja kojim se učenika potiče da se samostalno, ili u suradnji s drugima, u skladu s vlastitim sposobnostima i mogućnostima, intelektualno angažira, odnosno da stvara nova znanja i razvija nove vještine. Međutim, sama aktivnost učenika ne jamči razvoj kritičkoga mišljenja. Najjednostavnije rečeno, razvoj kritičkog mišljenja zahtijeva stvaranje svojevrsnog mikrookružja koje će učenike ohrabriti da se ne ustručavaju samostalno i ak-

\footnotetext{
${ }^{19}$ Usp. Facione, Critical Thinking..., 6-11.

${ }^{20}$ Usp. Lai, Critical Thinking..., 4.

${ }^{21}$ Usp. N. C. GLOCK, College Level and Critical Thinking: Public Policy and Educational Reform, https://eric.ed.gov/?id=ED298982 (20.03.2020); Kurfiss, Critical Thinking..., 21.

${ }^{22}$ Usp. L. G. SNYDER, M. J. SNYDER, Teaching Critical Thinking and Problem Solving Skills, The Delta Pi Epsilon Journal, 1 (2008) 2, 90-99.

${ }^{23}$ Usp. Paul, Eder, Consequential validity..., 2.

${ }^{24}$ Usp. Snyder, Snyder, Teaching Critical Thinking..., 93; Paul, Elder, Consequential Validity..., 5.
} 
tivno promišljati. ${ }^{25}$ Pri tome je uloga nastavnika poticanje znatiželje učenika, ohrabrivanje učenika da iznose prigovore i postavljaju pitanja, dok se od učenika očekuje ulaganje truda, pažnje i volje te primjenu tehnike samopraćenja. ${ }^{26}$ Jedan od važnih elemenata poticanja i razvoja kritičkoga mišljenja u procesu poučavanja i učenja je postavljanje odgojno-obrazovnih očekivanja tako da omogućuju razvoj vještina koje potiču kritičko mišljenje. Često se za polazište u definiranju odgojno-obrazovnih očekivanja uzima Benjamin Bloom i njegova taksonomija kognitivnih procesa, nastala 1956. Ona čini svojevrsnu polazišnu točku pri naglašavanju važnosti središnje uloge učenika u procesu poučavanja i učenja. Bloom u njoj razlikuje šest razina kognitivnih procesa koje su hijerarhijski prikazane. Prve tri razine - znanje, razumijevanje i primjena - obuhvaćaju niže kognitivne procese, dok tri najviše razine, a to su analiza, sinteza i evaluacija, čine više kognitivne procese te se nerijetko uzimaju kao polazište razvoja kritičkoga mišljenja. ${ }^{27}$ Međutim, postoje i kritičari povezivanja Bloomove taksonomije s razvijanjem kritičkoga mišljenja. Oni ističu da ona daje pogrešan uvid u to što je znanje, stavljajući ga na dno piramide kognitivnih procesa, dok, prema njihovu mišljenju, znanje mora biti krajnji cilj kritičkoga mišljenja. ${ }^{28}$ Osim toga, kritičari ističu i da je učenje proces, a ta primarna karakteristika učenja nije vidljiva i jasna iz tako hijerarhijski postavljene taksonomije. Kritiziraju i pokušaj da taksonomija bude vrijednosno neutralna budući da je to nemoguće i nespojivo $s$ vrijednostima pretpostavljenim u poučavanju kritičkoga mišljenja. ${ }^{29}$ Dakle, može se kazati da više razine kognitivnih procesa prema Bloomu ne znače nužno i razvoj kritičkoga mišljenja jer primjerice već razumijevanjem nekih kompleksnih pojava možemo razvijati kritičko mišljenje, kao što i procesom analize, a koja je viši kognitivni proces, možemo potaknuti proces pamćenja koje je, prema Bloomu, niži kognitivni proces. Drugim riječima, učenje i stjecanje znanja je kompleksan proces koji uključuje sve razine kognitivnih procesa, posebice pri razvoju složenih kompetencija kao što je kritičko mišljenje i ne može se ograničiti na statičnu hijerarhijsku piramidu.

Proces učenja, odnosno kognitivni razvoj, ovisi i o afektivnoj razini, točnije o emocijama pojedinca. Stoga se razvoj kritičkoga mišljenja u procesu poučavanja i učenja ne može vezati samo uz kognitivno područje razvoja pojedinca. Uvjetovanost kognitivne i emocionalne dimenzije, za kritičko mišljenje po-

\footnotetext{
${ }^{25}$ Usp. Paul i dr., Critical Thinking Handbook..., 21.

${ }^{26}$ Usp. Facione, Critical Thinking..., 17.

${ }^{27}$ Usp. A. LEWIS, D. SMITH, Defining Higher Order Thinking, Theory into Practice, 32 (1993) 3, 131-137; H. ASTLEITNER, Teaching Critical Thinking Online, Journal of Instructional Psychology, 29 (2007) 2, 53-77; T. BERS, Assessing Critical Thinking in Community Colleges, New Directions for Community Colleges, 2005 (2005) 130, 15-25.

${ }^{28}$ Usp. S. WINEBURG, J. SCHNEIDER, Was Bloom's Taxonomy pointed in the Wrong Direction?, The Phi Delta Kappan, 91 (2010) 4, 55-61.

${ }^{29}$ Usp. R. W. PAUL, Bloom's Taxonomy and Critical Thinking Instruction, Educational Leadership, 42 (1985) 8, 36-39.
} 
tvrđuju i istraživanja. ${ }^{30}$ Emocije jako utječu na djelovanje pojedinca, stoga nije neobično da se smatraju temeljnim motivom i poticajem procesa učenja. ${ }^{31} \mathrm{Kada}$ se u okviru odgoja i obrazovanja spominju emocije, uglavnom se misli na afektivno područje razvoja, na emocionalni rast pojedinca tijekom procesa učenja, a veže se uz vrijednosti, stavove, emocije i ponašanje. ${ }^{32}$ Važna karakteristika osoba koje su u stanju kritički misliti jest sposobnost vođenja računa o tome kako drugi razmišljaju, ${ }^{33}$ te stoga osoba koja je u stanju kritički misliti treba imati: intelektualnu poniznost, intelektualnu hrabrost, intelektualnu empatiju, intelektualnu integrativnost, intelektualnu upornost, vjeru u racionalne sposobnosti, intelektualno razumijevanje za pravdu. Važnost i nužnost povezanosti kognitivne i emocionalne dimenzije kritičkoga mišljenja naglašava se i u The Delphi Reportu, isticanjem da nema kvalitetnog poticanja i razvoja kritičkog mišljenja ako se iz tog procesa izuzme emocionalna komponenta. ${ }^{34}$ Dakle, kritičko mišljenje nije mišljenje bez emocija. Primjerice, bez emocije empatije, bez sposobnosti razumijevanja drugoga ili bez tolerancije, bez otvorenosti prema drukčijim pozicijama i prihvaćanje različitih ideja, ne bismo bili u stanju kritički promišljati situacije, pojave ili procese.

Proces poučavanja i učenja za kritičko mišljenje, budući da je kompleksan, zahtijeva odabir i primjenu strategija koje omogućuju aktivno učenje te metodički pluralizam. U literaturi se kao poželjne nastavne metode ističu primjerice: rješavanje problema, studije slučaja, igre uloga, osmišljavanje projekata, istraživački rad, simulacije itd. ${ }^{35}$ Zasigurno, svaka od ovih metoda, dobro osmišljenim aktivnostima učenika, može razvijati kritičko mišljenje, međutim, isto vrijedi i za bilo koji drugi način poučavanja kojem je cilj potaknuti učenika da analizira, procjenjuje i konstruira argumente, interpretira, samostalno zaključuje na temelju argumenata, primjenjuje stečena znanja u novim situacijama, kritički procjenjuje logičnost i valjanost informacija te rješava probleme.

\footnotetext{
${ }^{30}$ Usp. N. L. P. STEDMAN, A. C. ANDENORO, Identification of Relationships between Emotional Intelligence and Critical Thinking Disposition in Undergraduate Leadership Students, Journal of Leadership Education, 6 (2007) 2, 190-208; H. KAYA, E. ŞENYUVA, G. BODUR, Developing Critical Thinking Disposition and Emotional Intelligence of Nursing Students. A Longitudinal Research, Nurse Education Today, 48 (2017) 72-77; E. COMBER, Critical Thinking Skills and Emotional-Response Discourse. Merging the Affective and Cognitive in Student-Authored Texts through Taxonomy Usage, The Journal of the Assembly for Expanded Perspectives on Learning, 10 (2004) 73-85.

${ }^{31}$ Usp. W. D. WALL, Education and Mental Health, Paris, UNESCO, 1959, 29; D. R. KRATHWOHL, B. S. BLOOM, B. B. MASIA, Taxonomy of Educational Objectives, Book II. Affective Domain, New York, David McKay Company, 1964, 7.

${ }^{32}$ Usp. Krathwohl, Bloom, Masia, Taxonomy of Educational Objectives..., 7.

${ }^{33}$ Usp. Ennis, The Nature of Critical Thinking..., 2-4.

${ }^{34}$ Usp. Facione, Critical Thinking..., 13.

${ }^{35}$ Usp. Snyder, Snyder, Teaching Critical Thinking..., 93; M. S. MUNZENMAIER, N. RUBIN, Bloom's Taxonomy. What's Old is New Again, Santa Rosa, CA, The eLearning Guild, 2013, 11.
} 


\section{Metodologija}

\subsection{Postupak i uzorak}

Istraživanje je provedeno uz pomoć kvantitativne i kvalitativne metode analize sadržaja te komparativne metode. Cilj istraživanja je utvrđivanje koje su vještine kritičkoga mišljenja i koliko zastupljene u kurikulumima međupredmetnih tema. Za predmet istraživanja odabrane su međupredmetne teme zato što je Okvirom nacionalnoga kurikuluma predloženo ostvarenje ishoda tih tema u okviru predmetnih kurikuluma, bez obzira na vrstu i razinu obrazovanja. Analizom su obuhvaćeni ishodi učenja međupredmetnih tema jer se na temelju ishoda može najlakše utvrditi koliko aktivno učenici sudjeluju u procesu učenja i postaju li sposobni stvarati vlastite kritičke konstrukcije. Ishodi su analizirani na temelju šest kognitivnih vještina koje se smatraju temeljnim vještinama kritičkoga mišljenja - interpretacija, analiza, procjenjivanje, zaključivanje, objašnjenje i samoregulacija. ${ }^{36} \mathrm{Uz}$ pomoć navedenih kriterija analize određene su frekvencije navedenih vještina u kurikulumima međupredmetnih tema. Pored toga, međusobno su komparirani kurikulumi međupredmetnih tema da bi se utvrdilo postoje li razlike između međupredmetnih tema u poticanju razvoja vještina kritičkoga mišljenja.

Pretpostavka je da će ishodi učenja analiziranih kurikuluma biti formulirani tako da usmjeravaju razvoju kritičkoga mišljenja, te da među analiziranim kurikulumima s obzirom na vještinu kritičkoga mišljenja, neće biti značajnijih razlika. Ove se pretpostavke temelje na tome da ishodi učenja proizlaze iz postavljenih ciljeva učenja i poučavanja koji su kod svih međupredmetnih tema formulirani tako da ističu važnost poticanja i razvijanja kritičkoga mišljenja.

Istraživanje je provedeno na sedam kurikuluma međupredmetnih tema Građanski odgoj i obrazovanje, Poduzetništvo, Održivi razvoj, Osobni i socijalni razvoj, Učiti kako učiti, Uporaba informacijsko-komunikacijske tehnologije i Zdravlje. Ukupno je analizirano 351 ishod predložen za pet ciklusa obrazovanja koji uključuju osnovnoškolsko i srednjoškolsko obrazovanje.

\subsection{Rezultati i rasprava}

Uz pomoć opisa temeljnih vještina kritičkoga mišljenja ${ }^{37}$ razlikovani su oni ishodi međupredmetnih tema koji su formulirani tako da upućuju na razvoj vještina koje potiču kritičko mišljenje. Dobiveni rezultati analize ishoda učenja prikazani su tablicama.

\footnotetext{
${ }^{36}$ Usp. Facione, Critical Thinking..., 6.

${ }^{37}$ Usp. isto, 6-12.
} 
Tablica 1. Postotak zastupljenosti ishoda učenja kojima se potiče razvoj vještina kritičkoga mišljenja u pojedinim međupredmetnim temama

\begin{tabular}{|c|c|c|c|c|c|c|c|}
\hline & 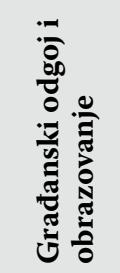 & 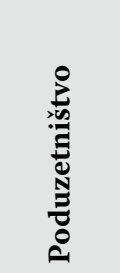 & 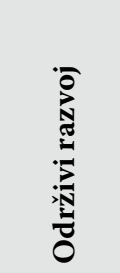 & 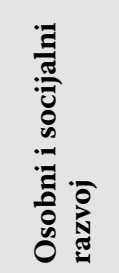 & 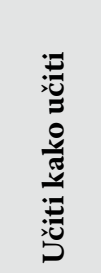 & 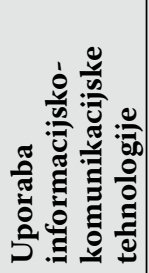 & 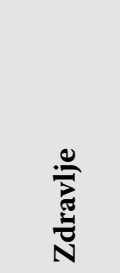 \\
\hline $\begin{array}{l}\text { Ishodi učenja } \\
\text { kojima } \\
\text { se potiče } \\
\text { kritičko } \\
\text { mišljenje }\end{array}$ & $94,73 \%$ & $30,55 \%$ & $63,88 \%$ & $67,39 \%$ & $8,92 \%$ & $50 \%$ & $59,49 \%$ \\
\hline
\end{tabular}

Iz tablice 1 jasno je da su odgojno-obrazovna očekivanja većine međupredmetnih tema formulirana tako da u visokom postotku, čak iznad $50 \%$, potiču kritičko mišljenje. Razloge tomu treba tražiti $\mathrm{s}$ jedne strane u ciljevima međupredmetnih tema iz kojih se izvode ishodi učenja, a kojima se ističe potreba poticanja razvoja kritičkoga mišljenja, a s druge strane u kompleksnosti kritičkoga mišljenja koje obuhvaća širok spektar različitih vještina. Najviše odgojno-obrazovnih očekivanja povezanih uz razvoj kritičkoga mišljenja ima kod međupredmetne teme Građanski odgoj i obrazovanje (94,73 \%), dok ih je najmanje kod međupredmetne teme Učiti kako učiti (8,92 \%). Razlog niskoj zastupljenosti ishoda učenja koji se odnose na razvoj kritičkoga mišljenja kod međupredmetne teme Učiti kako učiti vjerojatno je u metodologiji izrade tog kurikuluma jer je samo u toj temi kategorija kritičkoga mišljenja izdvojena kao posebna podskupina i ograničena je na jedan ishod po ciklusu obrazovanja. Visok postotak ishoda učenja koji uključuju vještine kritičkoga mišljenja kod međupredmetne teme Građanski odgoj i obrazovanje jasno ukazuje i na kompleksnost postavljenih ciljeva, ishoda i sadržaja te teme. On otvara pitanje eventualne potrebe predmetne realizacije ove međupredmetne teme s obzirom na spomenutu kompleksnost postavljenih ishoda učenja, odnosno mogućih problema njihova ostvarenja u sklopu pojedinih predmeta. Cjelovitiji odgovor na to pitanje zahtijeva, međutim, detaljniju analizu.

Iz tablice 2 je vidljivo da su sve vještine koje vode razvoju kritičkoga mišljenja zastupljene $u$ ishodima učenja Građanskog odgoja i obrazovanja, dok se $u$ kurikulumima Poduzetništva i međupredmetne teme Učiti kako učiti ne pronalaze tri od šest analiziranih vještina. Od svih analiziranih vještina najveću zastupljenost $u$ kurikulumima međupredmetnih tema ima vještina interpretacije i vještina analize, dok je najmanje zastupljena vještina zaključivanja, koja se ne pronalazi čak u četiri međupredmetne teme, te vještina procjenjivanja.

Analiza je pokazala da su kod pojedinih kurikuluma najviše zastupljene upravo one vještine koje najbolje odgovaraju sadržaju pojedinih tema. Tako 
Tablica 2. Vještine koje vode kritičkom mišljenju u ishodima međupredmetnih tema prikazane u postotcima

\begin{tabular}{|c|c|c|c|c|c|c|c|}
\hline & 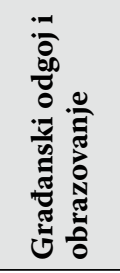 & 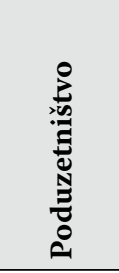 & 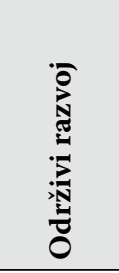 & 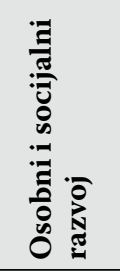 & 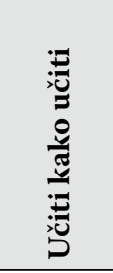 & 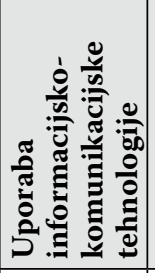 & 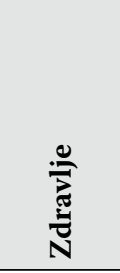 \\
\hline Interpretacija & $13,15 \%$ & $16,66 \%$ & $30,55 \%$ & $19,56 \%$ & $0 \%$ & $23,33 \%$ & $29,11 \%$ \\
\hline Analiza & $15,78 \%$ & $11,11 \%$ & $13,88 \%$ & $4,34 \%$ & $1,78 \%$ & $11,66 \%$ & $12,65 \%$ \\
\hline Procjenjivanje & $2,63 \%$ & $0 \%$ & $11,11 \%$ & $0 \%$ & $5,35 \%$ & $8,33 \%$ & $6,32 \%$ \\
\hline Zaključivanje & $5,26 \%$ & $0 \%$ & $0 \%$ & $2,17 \%$ & $0 \%$ & $6,66 \%$ & $0 \%$ \\
\hline Objašnjenje & $31,57 \%$ & $2,77 \%$ & $5,55 \%$ & $0 \%$ & $0 \%$ & $0 \%$ & $8,86 \%$ \\
\hline Samoregulacija & $7,89 \%$ & $0 \%$ & $2,77 \%$ & $41,3 \%$ & $1,78 \%$ & $0 \%$ & $2,53 \%$ \\
\hline
\end{tabular}

se, primjerice, kod međupredmetne teme Osobni i socijalni razvoj u najvećem postotku pronalazi vještina samoregulacije, dok su kod tema Održivi razvoj i Zdravlje to vještine interpretacije i analize.

Analiza ishoda učenja međupredmetnih tema pokazala je da se prilikom sastavljanja tih ishoda vodilo računa o postavljenim ciljevima međupredmetnih tema koji ističu važnost poticanja i razvijanja kritičkoga mišljenja. Međutim, poticanje razvoja pojedinih vještina kritičkoga mišljenja nije promišljano na jednak način kod svih međupredmetnih tema te $u$ ishodima učenja nisu podjednako uključene sve vještine koje vode kritičkom mišljenju. Za to može biti nekoliko razloga. Prvi može biti neujednačeno praćenje metodologije sastavljanja kurikuluma međupredmetnih tema. Može biti i to da su se kreatori pojedinih kurikuluma vodili isključivo Bloomovom taksonomijom koja hijerarhijskim prikazom odnosa pojedinih kognitivnih procesa nije dostatno dobra osnova za poticanje razvoja kritičkoga mišljenja, posebice uzme li se u obzir da je znanje krajnji cilj kritičkoga mišljenja, ${ }^{38}$ a u Bloomovoj taksonomiji tek najniža razina kognitivnoga razvoja pojedinca.

Ne ulazeći u polazišta postavljanja ishoda učenja u kurikulumima međupredmetnih tema i uzevši u obzir nedostatak znanstvene i stručne literature $u$ nas kada je u pitanju razvoj kritičkoga mišljenja u procesu odgoja i obrazovanja, može se tvrditi da su odgojno-obrazovna očekivanja međupredmetnih tema formulirana tako da potiču ostvarenje jedne od ključnih kompetencija 21. stoljeća.

${ }^{38}$ Usp. Wineburg, Schneider, Was Bloom's Taxonomy pointed in the Wrong Direction?..., 61. 


\section{Zaključak}

Teškoće pri definiranju onoga što je kritičko mišljenje ne čude budući da ta kompetencija obuhvaća brojna i kompleksna znanja, vještine i vrijednosti. Važnost razvoja kompetencije kritičkog mišljenja prepoznata je u inozemnim, ali i u našim odgojno-obrazovnim dokumentima u kojima se navodi kao kompetencija koju treba imati svaki pojedinac bez obzira na stupanj i vrstu obrazovanja. Unatoč tome da je u našoj znanstvenoj i stručnoj literaturi teško pronaći odgovore o načinu formuliranja odgojno-obrazovnih očekivanja tako da potiču razvoj kritičkoga mišljenja i o načinu poučavanja za kritičko mišljenje, a s obzirom na isticanje važnosti kritičkoga mišljenja u svim ključnim odgojno-obrazovnim dokumentima, moglo se očekivati da će kritičko mišljenje biti zastupljeno i u kurikulumima međupredmetnih tema. Ipak, provedena analiza otvorila je i neka pitanja. Primjerice, je li zbog složenosti kompetencije kritičkoga mišljenja potrebno inzistirati na posebnoj nastavnoj ili izvannastavnoj aktivnosti koja bi se bavila isključivo kritičkim mišljenjem ili treba govoriti o predmetnoj realizaciji nekih međupredmetnih tema? Uz to, s obzirom na visoku zastupljenost ishoda učenja koji uključuju vještine kritičkoga mišljenja, otvara se i pitanje adekvatnog obrazovanja nastavnika u poticanju, razvijanju i u konačnici vrednovanju kritičkoga mišljenja. Provedenom analizom ishoda učenja međupredmetnih tema ne može se odgovori na novootvorena pitanja, kao što se ne može dati konačan odgovor na pitanje obrazujemo li mlade tako da su u stanju kritički misliti. Odgovor na to pitanje traži opsežnije istraživanje koje bi uključivalo ispitivanje učenika, učitelja te analizu nastavnog procesa, posebice dijela procesa poučavanja i učenja koji se odnosi na ostvarenje postavljenih ishoda učenja. 


\section{Rona Bušljeta Kardum* \\ Development of Critical Thinking - Analysis of Learning Outcomes of the Cross-Curricular Subjects Curriculum \\ Summary}

The time we live and work in requires different competencies that will enable an individual to act better in all aspects of life. One of these competencies is critical thinking, which includes a number of different skills such as problem solving, decision making, reasoning and evaluation based on criteria. Since critical thinking is often considered to be one of the key competencies for living and working in the $21^{\text {st }}$ century, it is not surprising that the importance of developing critical thinking is emphasized when it comes to education. Although very little has been written about critical thinking in Croatia and within the educational process, the importance of developing critical thinking through the process of teaching and learning is emphasized by curricular documents. Thus, the aim of this paper is, based on the analysis of learning outcomes, detecting whether and to what extent cross-curricular subjects encourage the development of critical thinking. The results obtained will, in one hand, indicate the recognition of the importance of developing the competence of critical thinking in the process of education and, in the other, give some insight into the question of cross-curricular subjects successfully accomplishing their purpose which is, among other things, to encourage the development of competencies for the $21^{\text {st }}$ century. Given the complexity of this topic, further research is mandatory in pursuit of conclusion whether and to what extent cross-curricular topics contribute to the development of critical thinking.

Key words: critical thinking, cross-curricular subjects, curriculum, education, learning outcomes.

(na engl. prev. Rona Bušljeta Kardum)

\footnotetext{
* Rona Bušljeta Kardum, Assis. Prof., University of Zagreb, Faculty of Croatian Studies; Address: Borongajska cesta 83d, HR-10000 Zagreb, Croatia; E-mail: rbusljeta@hrstud.hr.
} 